\title{
THE ROLE OF GIS MAPPING METHOD IN TOPONYMY RESEARCH
}

\author{
Aygul YEGINBAYEVA ${ }^{1}$ \\ Kuat SAPAROV ${ }^{2}$ \\ Mariyash ARALBEKOVA ${ }^{3}$ \\ Emin ATASOY ${ }^{4}$ \\ Alaattin KIZILÇAOĞLU $U^{5}$ \\ Jan A. WENDT ${ }^{6}$
}

\begin{abstract}
Actual problems of toponymy are discussed in this article. The authors shows opportunities of using geoinformation and cartographic methods in toponymical investigation. Also in this research paper series of ancient place names and geographical terms are defined and a specific classification system of terms, based on specific data, is given (for example: oronyms, hydronyms, pasturable terminology and etc.). Etymology of Kazakh place names that shows physical and geographical characteristics of environment (landscape features, influenced by human activities, ecology and other factors), must be investigated in the scientific area.
\end{abstract}

Key Words: cartographical method, toponyms, geosystem, areas, landscapes, ancient maps, geoinformation mapping, toponymic atlas.

1 Department of Geography, 'L.N. Gumilyov' Eurasian National University, Astana, Kazakhstan, E-mail: aeginbaeva@mail.ru, k.sapar67@yandex.ru

2 Department of Geography, 'L.N. Gumilyov' Eurasian National University, Astana, Kazakhstan, E-mail: aeginbaeva@mail.ru, k.sapar67@yandex.ru

3 Department of Geography, 'L.N. Gumilyov' Eurasian National University, Astana, Kazakhstan, E-mail: aeginbaeva@mail.ru, k.sapar67@yandex.ru

4 Faculty of Education, Department of Elementary Education, Uludag University, Gorukle Campus, Bursa, Turkey E-mail: eatasoy@uludag.edu.tr Department of Social Sciences, Faculty of Necatibey Education, University of Balıkesir, Turkey

6 Institute of Geography Gdansk Poland, Gdansk University, Poland. 


\section{ÖZET}

\section{Toponomi Araştırmalarının Cbs Yöntemindeki Rolü ve Etkisi}

Bu makalede toponimi biliminin başlıca sorunları tartışılmaya açılmıştır. Geoinfosmasyon ve kartoğrafya yöntemlerinin toponomi araştırmalarındaki kullanımı, rolü ve etkisi irdelenmiştir. Ayrlca bu çalışmada tarihi toponimi kavramlarının mekân özelliklerine göre sistematiği ve sinıflandırması yapılmıştır. Kazakistan sinırları içinde yer alan fiziki coğrafya unsurları bilimsel yöntemlerle etimoloji ve toponimi penceresinden irdelenmişlerdir.

Anahtar Kelimeler: Kartoğrafya yöntemi, toponimi, geosistem, areal, landshaft, eski haritalar, geoinfosmasyon ve kartoğrafya, toponimi atlast.

\section{INTRODUCTION}

Geoinformational cartography method is widely used in the charting of landscape-toponymical maps. As a result, different scales topographic, geological, hydrological, geomorphological, soil, plants, animals maps, drawings, results of field observations, obtained by GPS, and historical archive, the oldest map data are used. Geographical maps have a lot of valuable information on historical data that makes it possible to define toponymy spelling and it's location. The most difficult issues in toponymy: collecting materials, data analysis, identification the origin of etymology. Toponymical research contain of such processes as collecting geographical names, recovering their previous origin names. The important role of map in toponymical research is known from ancient times. For example, the ancient Chinese, the Romans, the Greeks used toponymical method (including cartographic) while planting, building roads, digging irrigation canals etc. There are some information about ancient toponyms on the map (ringshaped) created by Mahmoud Kashgari, a prominent scholar, who lived in the Middle Ages. N. Nadezhdin in his research called "Russian historical geography experience" shows that the geographic maps play an important role in the toponymical researches and have a lot of information systems. It can be seen on his winged phrases.

\section{THE ORIGINAL DATA AND RESEARCH METHODS}

The names of each land and water are like documents confirming the nature of this region. "Earth is the humanity book written in historical and geographical names languages" (Nadezhdin 1837). Diachronic and synchronic analysis play an important role in describing differences between ancient time and modern Kazakh languages, local speeches and spatial 
dialects. Such kind of analysis can be done on the basis of ancient geographical maps and scientific papers (Kaymuldinova 2001). For example: the book of A. Maksheev, published in 1627, "Big Sketch book" (Maksheyev 1880) and the book of Swedish Gustav Renat "Dzhungarian map" (1716-1733) (Maksheyev 1888) have analysis of conformity between geographical names and toponyms of those time. For example, according to A. Maksheev, in "Big Sketch book" the names of rivers Aspaga and Kuuey changed to Buldyrty and Kandygayty, Sauyk to Torgai, Sun Gurluk (Kungirlek) to Hobda (Kobda), Bozyn-Ginchal-Ilgen (perhaps created by Bozingen) to Ulka-ayak (Olkeiyek) respectively (Maksheyev 1880).

Ancient toponyms of Pavlodar region are reflected in S. U. Remezov's (1697) map. On the map of S. U. Remezov west from the left bank of the Irtysh River there is "Shabakta (Shabakty) island", "Shepeleu rock", and then "Yar (Zhar) Alladerdyev", "Staryi Irtysh", at the forwardcollars; further Kyzyl zhar and other toponyms. West of Keregejar there is "Belye vody" (Aksu), "Ostrog Kalmyckoy" and "The tract Kabalgansun, and then "The tract Dolon (zheti) Karagay", and "Lake Enkul", etc. At the same time we can see that S.U. Remezov replaced some toponyms from the right bank of the river Irtysh to the left site. Although in this ancient map toponymical origin of the Middle Irtysh region well-preserved (Artykbayev, Ermanov and Dauyenov 2006).

However, distortion characteristics of mentioned toponyms are defined through word combinations. F. Usov in his works have a lot information about "Koryakov Yar" name near the river Irtysh (Usov 1879). This data means that toponymical names "Koryakov Yar" or "Kerege zhar" are widely used in the beginning of XVII century and were used like geographical landmark.

"From Kereku zhar to the west", "Urochishe 9 bugrov", and "Baklannaya zaostrova, Rybnaya", and "Kachir" (Kashir), 8-yarov Urochishe rizhih zherebcov (Osmorijsk), to the north "Irlytyup Yar" (Urlityub), "Saygachy Yar" (Saigak zhary) and continuing. To the east Kerege Zhar "Verblyuzhyi Yar", "Toloknyannye gory", and "Jamshi" (Yamysh) lakes and other orographic and hydrographic objects reflected in the map below (Artykbayev, Ermanov and Dauyenov 2006). All these objects give a lot of geoecological information from ancient history. Therefore, geographical maps are often used while determining features of toponymy. Because maps have a quantitative and qualitative data that can be useful for further investigation (Figure 1) (Saparov 2001). 


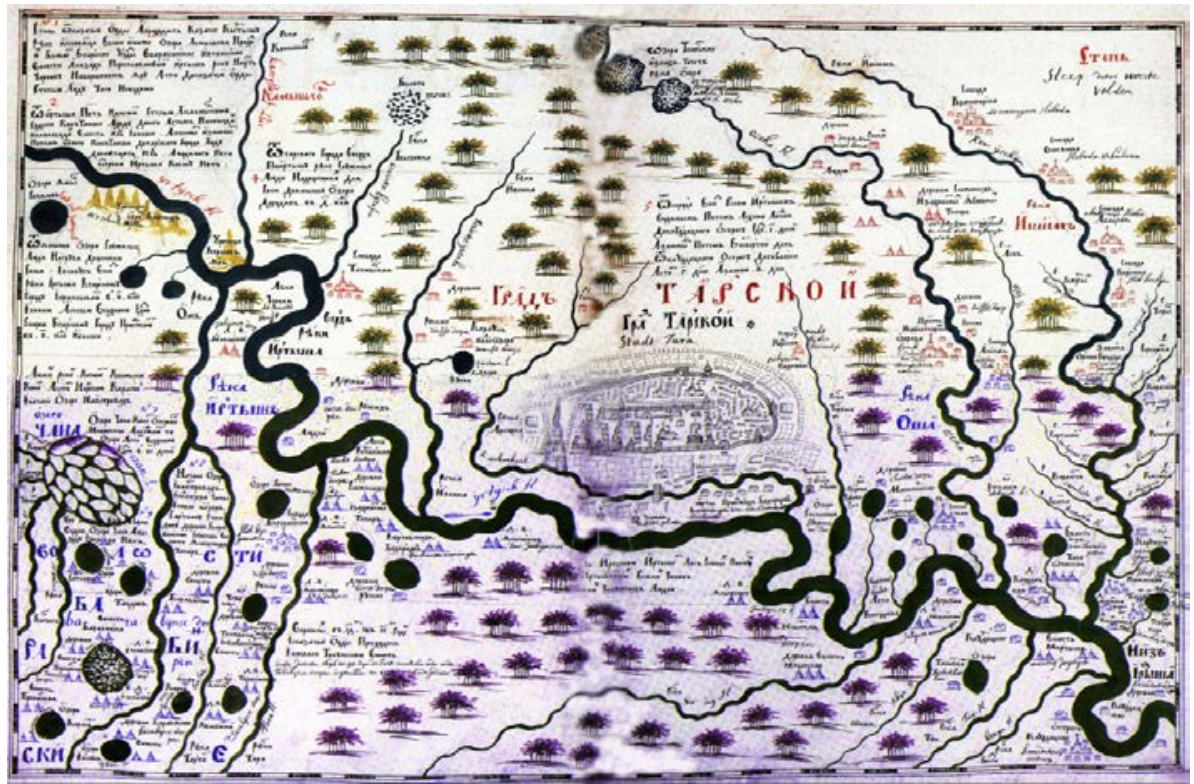

Fig. 1. S. U. Remezov "Siberia Sketch" cartographic map of geographical objects located along the Irtysh River (1697 y.)

\section{MAIN PART}

Shokan Valihanov is the first scientist and discoverer among researchers who investigated Middle Asia and paid special attention to toponymy issues. He did an important scientific research in geography of eastern nation. Names of land and water collected as a result of his geographical excursions have invaluable heritage for future generations (Valikhanov 1984).

It is known that the base of Areal (lat. Area - area, space) linguistics created by neolinguistic school (J. Bonfante, J. Bartoni, J. Barto, etc.) at the beginning of the XX century in Italy. However, in the second half of the XIX century, scientists like Y. Schmidt, G. Venker, F. Vrede are widely used this method to define and show dialects' spread places (Bondaletov 1983).

According to some data A. Shleykher, G. Paul, I. A. Boduen de Curtene, G. Shukhardt, N. S. Trubetskoy told about the mixture of languages, the llinguistic alliance and the convergence phenomenon before neolinguists. Nevertheless, it is assumed that main terms and principles of areal linguistics established by neolinguists (Sharadzenidze 1983).

The areal method of linguistics should be used at the same level like comparative and typological methods to identify relation and connection 
between language and group of languages. Unfortunately the areal method of linguistics remains in the shadows of comparative and typological methods. Well known linguist F. Bopp and his disciples who lived in the XIX century used historical comparative method to prove languages relation and the whereas epy areal method of linguistics was unnoticed. This omission reflected in linguistic study today.

The areal linguistic study closely connects with the convergence process (influence and convergence of related or unrelated languages), mixed languages issues, languages alliances, bilingualism and dialects spread places. Because after publishing «The linguistic atlas of France» created by J. Zhileron and E. Edmond at the beginning of the century (1910 year) the geographic method in linguistic study are started to use. Further dialectological atlases of Italy, Romania, Spain and Switzerland were published one after another (Biyarov 2012).

Also the areal method of research (cartographic, map, isoglostic, linguistic geography methods) can be used in lexicology also referred to as methods of linguistic geography) are to be used in the onomastics field of lexicology. The fist scientist who successfully used cartographic data method in toponymic research was F. Engels. F. Engels applied 1: 200000 scale topographic maps to approve analysis of toponyms in his research work "Frankish dialect" (Engels 1935).

Frequent using of cartographic methods in geography positively influences on the development of toponymy. The first information about toponymic atlases were published in Sweden (Swedish toponymy Atlas, 1942), and later in Venice (Tridentina) toponymy atlas (Atlante, 1953) (Pospelov 1971).

IX International Onomastic convention, which took place in London in 1966 the issue completing of world hydronomical atlas was discussed. Likewise «The toponymy atlas of the Czech Republic», and other maps of different scales were constructed. In Soviet Russia K. A. Salishev was the first who formed and put contribution to the development of the cartographic method in scientific sphere (Salishchev 1948). Then, V. A. Nikonov and A. S. Strizhak used cartographic method in their research works named "Geography of Russian suffixes" and "Onomastics in Ukraine" to identity spread places of toponyms and topoformants, respectively (Bondaletov 1983).

To provide correct and consistent applying of cartographic method in geographical names research E. M. Pospelov wrote "Toponymy and Cartography» scientific work in 1971. He showed the role of the cartographic method in land and water names research and proved it's close connections with toponymy (Salishchev 1948). 
Eventually advantage of using the cartographic method in toponymy became clear. While determining spread areas of toponyms, including hydronyms, oronyms and others, defining landscapes, different geographical terms and formants, mapping justified all expectations. In anthroponym, cosmonium and other fields of onomastics isoglostic research methods began to be widely used.

\section{RESULTS AND DISCUSSION}

Although toponymy is individual and independent field of science today, originally it depends on linguistics, history and geography. Land and water names can refer to one of these mentioned field of science. Areal method brought toponymy and geography together and we can consider them like one system.

The rest of researchers who investigate geographical names were historians and scientists geographers engaged in the construction of maps. Firstly they drew topoobjects on maps, then wrote names of topoobjects and scientists need to pay attention on land and water names. For example, significant contribution to Turkic toponymy was made by E. M. Murzaev, E. M. Pospelov, G. Konkashbayev, basically, were experts in the field of geography (Biyarov 2012).

Such as toponymy "cartography is individual field of technical science, but this science is very close to geography, geodesy and topography" (Salishchev 1948). Toponomy scientifically proves the correctness of geographical names and at the same time cartography provides toponymy with cartographic research methods. The main task of this method is to collect names, finding historical data in geographical names research by using maps. For example, bases on the northern Chinese historical data and maps Kyrgyz in the II century B. C. moved from place to place along the Yenisei river, that means in kyrgyz language "those river" (Malyavkin 1981).

Another task of cartographic research method is construct toponymic maps on specific toponymy field or topics (nomens, word formation system, phonetic features, etc.). We think the second method is more important than the first one that bases on writing down names from the maps. E. M. Pospelov said that such kind of maps, atlases belong to cartography - by "methods", and to toponymy by "content" (Salishchev 1948).

The close relation between topography and cartography formed two directions of science. One of them is called "cartographic toponymy" and the second one - «toponymic cartography». The first is part of toponymy that serves for cartography. In particular, the spacial topographic works base on writing correct names of objects and identification its' original forms, 
languages, translations from one to another language, orthography of land and water names, assessment of toponymic atlases' content and other issues. Although all these tasks belong to cartography, they can be realized only with toponymy. Using only one of them leads to incompletely execution of tasks. Our main aim is not to mapping with the help of toponymy, conversely make toponymic investigation based on the cartographic methods. Maps and atlases constructed by the government mapping agencies that works together with toponymy specialists and sometimes have gaps and discrepancies. We can see such kind of discrepancies on some maps of Kazakhstan. For example, 1:2000 000 scale map of the Republic of Kazakhstan has obvious misprints Dagandeli (Dag'andely), Saryshygan (Saryshag'an), Zhitikara (Zhetikara), Emba (Embi). However the hydronym Zaysan written in spoken language version - Zhaysan (Biyarov 2012).

Specific literature and research papers about toponymic cartography are random. As for the toponymy of Kazakhstan internal cartographic methods are used in the doctorate dissertation works of K. D. Kaimuldinova, K. T. Saparov and candidate dissertation works of A. S. Omarbekova, A. E. Ayapbergenova, A. O. Makanova. Moreover, these mentioned dissertations provides a geographical point of view (Biyarov 2012).

\section{CONCLUSION}

While investigating the east, the north-east Kazakhstan toponyms that shows environmental conditions of the area K. T. Saparov researched physical, geographical, landscapes and geoecologycal features of toponyms and created specific toponymic maps system (9 maps).

Also he defined toponymic system and the number of geographical terms of nation, then grouped them in system (oronyms, hydronyms, pasturable terminology and etc.) (Saparov 2010). Kazakh toponyms units that reflecting the physical and geographical features of natural environment, properties of landscapes, economy, ecology should be investigated in each region.

Today the system of toponyms of Kazakhstan not totally investigated in each region (geographic area). Firstly it is necessary to analyze all collected names and create «Toponymic atlas of Kazakhstan». The next stage is to use geoinformation and cartographic method. Consequently in all aspects of toponymic research (historical-ethnographic, linguistic, geographic and etc.) systematic grouping of toponyms bases on geoinformation system is very important. Construction different scale toponymic maps, in turn, requires a lot of research and studies (in fields, archive, cartography). 


\section{REFERENCES}

Artykbayev ZH. O., Ermanov A. ZH. and Dauyenov E. N. (2006), Toponymical issues medium Priirtyshie. Pavlodar: "Golden Book". p. 151.

Biyarov B. N. (2012), Derivational form of the names of the land and water: monograph. Almaty: The State language Development Institute. p. 460.

Bondaletov V. D. (1983), Russian onomastics. Moscow: Education. p. 224.

Engels F. (1935), Frankish dialect. Moscow. p. 237.

Kaymuldinova D. (2001), Ethno-ecological bases of the Kazakh toponyms. Textbook. Almaty: Science. p. 92.

Maksheyev A. (1880), Geographic information Book of the Big Drawing on the Kirghiz steppes and Turkestan edge // Notes of the Russian Geographical Society in the department of ethnography. Tom 6. Division II. St. Petersburg. p. 1-41.

Maksheyev A. (1888), Map Dzhungaria, compiled by Renat in 1716-1733 yy. // Notes of the Russian Geographical Society in the department of general geography. Tom XI. p. 105-145.

Malyavkin A. G. (1981), Historical geography of Central Asia (materials and research). Novisibirsk: Science. p. 336.

Nadezhdin N. (1837), Experience of historical geography of the Russian world. "Library for reading". Tom XXII. St. Petersburg.

Pospelov E. M. (1971), Toponymics and cartography. Moscow: Thought. p. 255.

Salishchev K. A. (1948), Fundamentals cartography. Part historical and cartographic materials. Moscow. p. 296.

Saparov K. T. (2001), Ways of formation of some of the names of land Irtysh River Basin // Materials of the scientific and practical conference "Zhandayev Readings". Alma-Ata. p. 158-160.

Saparov K. T. (2010), Geographic Foundations of Toponyms Formation in Kazakhstan (by example of northeastern and eastern regions). Abstract of the thesis of Doctor of Geographical Sciences. Almaty, p. 32.

Sharadzenidze T. S. (1983), Study convergence languages and linguistic alliance // The genetic, areal and typological communications languages of Asia. Moscow: Science. p. 69-79.

Usov F. (1879), Statistical description of the Siberian Cossack Force. St. Petersburg. p. 46.

Valikhanov CH. (1984), Collected works: in 5 t. Alma-Ata: Main edition of the Kazakh Soviet encyclopedia. Tom. 4. p. 460. 